SALAM; Jurnal Sosial \& Budaya Syar-i

FSH UIN Syarif Hidayatullah Jakarta

Vol. 7 No. 9 (2020), pp. 763-774, DOI: 10.15408/sjsbs.v7i9.16591

\title{
The Jurisdiction of Sharia Supervisory Board in Indonesia Sharia Capital Market*
}

\author{
Bagas Heradhyaksa ${ }^{1}$ \\ Faculty of Sharia and Law, Walisongo State Islamic University, Semarang \\ doi $10.15408 /$ sjsbs.v7i9.16591
}

\begin{abstract}
The capital market is an institution that brings together those who need funds, to develop their business, and those who are excess funds, to make investments. Unlike the concept of financing in banks, the capital market uses the concept of buying and selling shares. So that it can be a solution for a company that wants to develop its business without using debt. Investors can also get profits that are higher than the profits from bank deposits. Thus, the capital market is growing in the middle of society. However, there are some activities in the capital market that are contrary to Islamic principles. Therefore, the Islamic capital market emerged. To oversee activities in the Islamic capital market, the role of the Sharia Supervisory Board is needed. The objective of this article is to find out the jurisdiction governing the Sharia Supervisory Board in the Islamic capital market in Indonesia. The methodology used is qualitative research. The data used in this study is library data. This study found that the existence of the Sharia Supervisory Board already has a legal basis based on the Indonesian Financial Services Authority Regulation. However, there are no specific laws governing the Islamic capital market. So it is necessary to make a special law that accommodates all aspects of sharia in the Islamic capital market, specifically with regard to the Sharia Supervisory Board.
\end{abstract}

Keywords: Capital Market, Sharia Capital Market, Sharia Supervisory Board, Jurisdiction, Indonesia.

\begin{abstract}
Abstrak
Pasar modal adalah lembaga yang mempertemukan mereka yang membutuhkan dana, untuk mengembangkan usahanya, dan mereka yang memiliki kelebihan dana, untuk melakukan investasi. Berbeda dengan konsep pembiayaan di bank, pasar modal menggunakan konsep jual beli saham. Sehingga dapat menjadi solusi bagi perusahaan yang ingin mengembangkan usahanya tanpa menggunakan hutang. Investor juga bisa mendapatkan keuntungan yang lebih tinggi dari keuntungan dari deposito bank. Dengan demikian, pasar modal tumbuh di tengah masyarakat. Namun, ada beberapa aktivitas di pasar modal yang bertentangan dengan prinsip syariah. Oleh karena itu, pasar modal syariah muncul. Untuk mengawal aktivitas di pasar modal syariah, diperlukan peran dari Dewan Pengawas Syariah. Artikel ini bertujuan untuk mengetahui yurisdiksi yang mengatur Dewan Pengawas Syariah di pasar modal syariah di Indonesia. Metodologi yang digunakan adalah penelitian kualitatif. Data yang digunakan dalam penelitian ini adalah data perpustakaan. Studi ini menemukan bahwa keberadaan Dewan Pengawas Syariah sudah memiliki dasar hukum berdasarkan Peraturan Otoritas Jasa Keuangan. Namun, tidak ada undang-undang khusus yang mengatur pasar modal syariah. Sehingga perlu dibuat undang-undang khusus yang mengakomodir semua aspek syariah di pasar modal syariah, khususnya yang berkaitan dengan Dewan Pengawas Syariah.
\end{abstract}

Kata Kunci: Pasar Modal, Pasar Modal Syariah, Dewan Pengawas Syariah, Yurisdiksi, Indonesia.

\footnotetext{
* Diterima: 13 April 2020, Revisi: 2 Juli 2020, Diterbitkan 03 September 2020.

${ }^{1}$ Bagas Heradhyaksa is a lecturer at Faculty of Sharia and Law, Walisongo State Islamic University, Semarang. E-mail: bagashera@walisongo.ac.id.
} 


\section{A. INTRODUCTION}

The rapid development of the global economy has a serious impact. When the intended impact is good, the economy can run smoothly. But if adverse effects occur, it can cause problems in a country's economy. Like the problem of the threat of a monetary crisis. One of the efforts made by Indonesia to improve economic growth is to develop the investment sector by using Financial Market instruments. Financial Market has an important role in the economy of a country because it can bring together those who have excess funds with those who need funds. Without a financial market, money lenders (creditors) will have difficulty in finding debtors who are willing to provide loans to them. There are two types of financial markets, namely the capital market, and the money market. The capital market trades securities in the long-term funds, such as stocks, bonds, derivatives, and mutual funds. Whereas, the money market is a meeting between the demand and supply of short-term funds. ${ }^{2}$

The capital market has two functions, economic function, and financial function. In the economic function, the capital market provides facilities to bring together two interests, those who are surplus funds (investors) and those who need funds (issuers). With the capital market, parties with surplus funds can invest these funds in the hope of obtaining a return, while the company (issuer) can utilize these funds for investment purposes without waiting for the company's operational funds to be available. In the financial function, the capital market provides the possibility and opportunity of obtaining a profit (return) for the owner of the fund, according to the selected investment characteristics. ${ }^{3}$ This makes the capital market have an important role in a country's economic system. In it are connected so many economic actors without State borders. It could be that capital market players in Indonesia come from many countries.

The first Islamic mutual fund in Indonesia was issued in 1997. Furthermore, in 2000, the Jakarta Stock Exchange in collaboration with PT Danareksa Investment Management launched the Jakarta Islamic Index. The Government of Indonesia through the Ministry of Finance, the Capital Market Supervisory Agency, and the Indonesian Ulema Council officially launched the Islamic capital market on March 14, 2003. The issuance of Indosat Mudharabah Syariah Bonds in 2002. While internationally, Dow Jones has launched the Dow Jones Islamic Market Index in February 1999.4 This shows that the Islamic Capital Market instruments are profitable. The Sharia Capital Market is not only to meet the religious needs of Muslim communities but can also provide

2 Anna Nurlita, 2015. 'Investasi Di Pasar Modal Syariah Dalam Kajian Islam', Kutubkhanah: Jurnal Penelitian Sosial Keagamaan, 17.1 (2015), 1-20

http://ejournal.uin-suska.ac.id/index.php/Kutubkhanah/article/download/806/766>

${ }^{3}$ Faiza Muklis, 2016. Perkembangan Dan Tantangan Pasar Modal Indonesia', Al Masraf (Jurnal Lembaga Keuangan Dan Perbankan), 1.1 (2016), 1-12.

4 Sri Ramadhan, 2016. 'Pasar Uang Dan Pasar Modal Dalam Perspektif Ekonomi Islam', Al-Masraf: Jurnal Lembaga Keuangan Dan Perbankan, $1.2 \quad$ (2016), 197-210. http://journal.febi.uinib.ac.id/index.php/almasraf/article/view/56 
benefits. The concept of Islamic sharia is considered safer and provides strength that can withstand the global crisis resulting from market play. ${ }^{5}$

The Financial Services Authority, as the authority that fosters and oversees capital market activities in Indonesia, actively encourages the development of sharia products in the Indonesian capital market. Various policies are outlined in the 2015-2019 Indonesian Sharia Capital Market Road Map which includes strategies and programs that are a continuation of the strategies and programs contained in the Indonesian Capital Market Master Plan 2005-2009 and 2010-2014, as well as several special regulations governing the issuance of sharia products on the Indonesian capital market since 2006. ${ }^{6}$ This shows that the government also supports the development of the Sharia Capital Market in Indonesia.

The development and movement of global markets have caused the Indonesian stock market to experience periods of ups and downs. One of the movements was caused by several major events such as the crisis that occurred in Asia in 1997/1998 and the subprime mortgage crisis in America in 2007/2009. Empirical studies related to the comparison of the performance of conventional capital markets and Islamic capital markets in various countries have often been carried out. The results show that the performance of the Islamic capital market in Malaysia provides better returns than the performance of conventional capital markets in all study periods, namely before, during, and after the subprime mortgage crisis in the United States. ${ }^{7}$

Trading on the stock exchange is closely related to market psychology. Investors are vulnerable to issues that hit the bourse, few issues that sometimes are not directly related to the financial fundamentals of the issuer, investors have panicked. Especially if the issue is global, then investors are ready to sell or buy. Besides, investors tend to follow foreign investors who have a large capital, although they must ignore the financial fundamental factors of the issuer. This is what makes the market can run naturally and efficiently. ${ }^{8}$

The application of sharia principles in the capital market certainly comes from the Qur'an as the highest legal source and the Hadith of the Prophet Muhammad PBUH. Furthermore, from the two legal sources, the scholars interpreted what came to be called the science of figh. One of the knowledge learned in figh is about muamalah. Muamalah is a relationship between human beings related to trade. Based on that sharia capital market activities are developed based on muamalah fiqh. There are muamalah fiqh rules which state that "Basically, all forms of muamalah are permissible unless there is an

\footnotetext{
${ }^{5}$ Subaidi, 2017. 'Rekonstruksi Hukum Pasar Modal Syariah Dalam Memberi Jaminan Kepastian Hukum', Istidlal: Jurnal Ekonomi Dan Hukum Islam, 1.2 (2017), 155-66 https://doi.org/10.35316/istidlal.v1i2.105

${ }^{6}$ M Fauzan and Dedi Suhendro, 2019. 'Peran Pasar Modal Syariah Dalam Mendorong Laju Pertumbuhan Ekonomi Di Indonesia', Prociding SENDI, 2019, 978-79.

7 Budi Setiawan, 2017. 'Perbandingan Kinerja Pasar Modal Syariah Dan Konvensional : Suatu Kajian Empiris Pada Pasar Modal Indonesia', Jurnal Ilmiah Ekonomi Global Masa Kini, 8.1 (2017), 35-40

${ }^{8}$ Gusniarti. 2015. ‘Perdagangan Saham di Pasar Modal Syariah Perspektif Ekonomi Syariah (Studi Kasus Bursa Efek Indonesia)’. Al-Intaj, 1(1), (2015) 1-18.
} 
argument forbidding them." This concept is used in Islamic capital market activities in Indonesia..$^{9}$

One of the fundamental differences between the organizational structure of Islamic financial institutions and conventional financial institutions is the necessity of the Sharia Supervisory Board in Islamic financial institutions. The Sharia Supervisory Board is a board of economists and scholars who are in charge of the Islamic commercial jurisprudence sector which is independent and must observe and supervise the operations of Islamic financial institutions and all of its products to comply with Islamic regulations. Another difference between Islamic financial institutions and conventional financial institutions is the obligation to fulfill compliance with Islamic principles. Every implementation of business activities in Islamic financial institutions must fulfill compliance with sharia principles that are implemented in its products, services, and

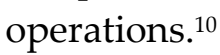

Supervision of Sharia Financial Institutions to remain compliant with sharia principles is an important issue in maintaining its reputation as a financial institution based on Islam. Public trust in the products of Sharia Financial Institutions that are halal, safe, and appealing must be maintained by reinforcing the supervision system. Supervision is needed to control so that no deviations occur from the objectives to be achieved, and from the rules set. Supervision is also an activity of correction and improvement to the goals and rules that are known to deviate. Weak monitoring systems will encourage fraud and fraud that can cause harm to related parties or the general public. ${ }^{11}$ The need for certainty in the fulfillment of sharia has encouraged the emergence of a new audit function, namely shariah auditing. Because of the rapid growth of the sharia industry, Islamic financial institutions need to have adequate checks and balances regarding the mechanism in the form of sharia audits that are following the objectives and mission of the maqasid al-shariah. ${ }^{12}$

National Sharia Council-Indonesian Ulema Council and Sharia Supervisory Board are the parties assigned to ensure that the fulfillment of sharia principles in the economic sector is carried out to the fullest. ${ }^{13}$ In practice, the Sharia Supervisory Board as an independent institution that oversees the operation of Islamic financial institutions receives incentives and benefits from overseen sharia entities where the entity still has an administrative relationship in the administrative management structure, ie not from an independent institution outside the administrative management of entities that do not have direct administration in the structure of the organization they oversee, so that

\footnotetext{
${ }^{9}$ Muhammad Abduh, 2015. 'Penerapan Prinsip Ekonomi Islam Dalam Pasar Modal Syariah', Jurnal 'Adliya, 9.1 (2015) 99-114.

${ }^{10}$ Akhmad Faozan, 2014. 'Optimalisai Peran Dewan Pengawas Syariah Pada Lembaga Keuangan Syariah', Jurnal El-Jizya, II.1, (2014) 23-40.

${ }^{11}$ Neneng Nurhasanah, 2013. 'Pengawasan Islam Dalam Operasional Lembaga Keuangan Syariah', MIMBAR, Jurnal Sosial Dan Pembangunan, 29.1 (2013), 11. https://doi.org/10.29313/mimbar.v29i1.362

12 Nadia Farhana Izzatika; and Ahmad Tarmidzi Lubis, 2019. Isu Dan Tantangan Kompetensi Dewan Pengawas Syariah Di Indonesia. Jurnal Akuntansi Dan Keuangan Islam, 4(2)

${ }^{13}$ Ai Nur Bayinah, Sepky Mardian, Sri Mulyati, Erina Maulidha, 2018. Akutansi Asuransi Syariah, Jakarta: Salemba empat, h.57.
} 
from this conflict of interest can occur where the sharia entities they oversee always want to get the status of shariah compliment, but on the other hand, the Sharia Supervisory Board does not want to lose their positions and monthly incentives so that it can only report good things to the entity. ${ }^{14}$

The Islamic capital market is one of the Islamic Financial Institutions. Therefore, activities in the Islamic capital market must not conflict with Islamic principles. One of the reasons people choose the Islamic capital market is to avoid activities that are contrary to Islamic principles in the conventional capital market. For this reason, a Sharia Supervisory Board is needed to oversee the activities of the Islamic capital market.

\section{B. RESEARCH METHODOLOGY}

To describe the discussion in this research, several research sources are needed in the form of primary and secondary materials, such as books, texts, and journal articles. The research method used is normative and qualitative research type.

\section{ANALYSIS AND DISCUSSION}

\section{Definition of Capital Market}

The capital market in Indonesia has a long history of operation since 1912 when Indonesia was still under Dutch colonial rule. At that time the Indonesian capital market traded shares and bonds of Dutch-owned plantation companies. The Indonesian stock market stopped operating in 1942 because the Netherlands was occupied by Germany during the World War. In the early 1950s, the stock market reopened, but the market was inactive due to changes in economic and political dynamics. ${ }^{15}$

The capital market is synonymous with a place where capital is traded by investors, those who have excess capital, with the issuer, and those who need capital to develop investment. Capital market definition based on Law No. 8 of 1995 section one explains that the Capital Market is an activity concerned with public offering and trading of securities, public companies related to the issuance of securities, and institutions and professions related to securities. Based on this understanding, it can be simply understood that the capital market is a means for fundraising activities for the seller of funds or the buyer of funds or the issuer. Fund buyers are institutions or business entities that need capital for their companies. Whereas the seller of funds is the investor both individually and in groups. Capital that has developed efficiently is accommodated by the parties as a fair milestone for capital market players, namely companies, investors, and brokers.

In a narrow sense, a capital market is a place in an organized physical sense where securities are traded called the stock exchange. Understanding the stock exchange is an organized system that brings together sellers and buyers of securities carried out either directly or indirectly. ${ }^{16}$ Whereas the definition of a stock exchange based on Law No.8 of

\footnotetext{
${ }^{14}$ Khotibul Umam, 2015. 'Manajemen Perbankan Syariah', Bandung: CV Pustaka Setia.

${ }^{15}$ Budi Setiawan, 2017. 'Perbandingan Kinerja Pasar Modal Syariah dan Konvensional : Suatu Kajian Empiris Pada Pasar Modal Indonesia', Jurnal Ilmiah Ekonomi Global Masa Kini, 8.1 (2017), 35-40

${ }^{16}$ Faiza Muklis, 2016. 'Perkembangan Dan Tantangan Pasar Modal Indonesia', Al Masraf (Jurnal Lembaga Keuangan Dan Perbankan), 1.1 (2016), 1-12.
} 
1995 is that a Securities Exchange is a person who organizes and provides a system for uniting buy and sell offers with the aim of trading securities between them.

\section{Definition of Sharia Capital Market}

Sharia Capital Market is an activity that is related to public offering and trading of securities, public companies related to the issuance of securities, and institutions and professions related to securities that are carried out based on sharia principles. ${ }^{17}$ Based on Law Nomor 8 of 1995, a public offering is a securities offering activity carried out by an Issuer to sell securities to the public based on the procedures stipulated in this Law and the implementing regulations. Whereas securities consist of debt instruments, commercial securities, shares, bonds, debt proofs, Participation Units of collective investment contracts, futures contracts on Securities, and any derivatives of Securities.

The Islamic capital market in Indonesia is also regulated by the National Sharia Council Regulation of the Indonesian Ulema Council No. 40/DSN-MUI/X/2003. The regulation governs the types of businesses, products, services, and contracts and how to manage listed companies or public companies that issue sharia securities must not contradict sharia principles. The regulation also regulates that the transaction must be carried out according to the principle of prudence and it is not allowed to carry out speculations and manipulations which contain elements of dharar, gharar, riba, maisir, riswah, maksiyat, zhalim. The activity which contained the first forbidden elements was Najsy, which was to make a fake offer. Second, Bai 'al-a'dum, which is selling goods (sharia securities) that are not yet owned (short selling). Third, Insider trading, which uses inside information to gain profits on prohibited transactions. Fourth, giving rise to misleading information. Fifth, investing in listed companies, and at the same time making loans to conventional financial institutions is more dominant than the capital. Sixth, margin trading, which is conducting transactions on sharia securities with an interest-based loan facility for the obligation to settle the sharia securities. Seventh, ikhtikar or commonly referred to as hoarding, is an activity to purchase or collect sharia security to cause changes in the price of sharia securities. This is done to influence other parties. Other transactions that contain this element are also prohibited in Islamic capital market activities.

\section{Definition of Sharia Supervisory Board}

As a business industry that emphasizes more on the aspects of public trust, Islamic financial institutions will truly lose their reputation in the community if in their business practices they indicate violations of Islamic principles. Therefore, the Sharia Supervisory Board has an important role as an independent institution that oversees the suitability of products and operations of Islamic financial institutions with Islamic principles so that they can provide guarantees and foster public confidence in conducting transactions in Islamic financial institutions. ${ }^{18}$

In the organizational structure of sharia financial institutions, the Sharia Supervisory Board is located at the level of a board of directors. This is to ensure the

${ }^{17}$ Muhammad, 2020. 'Bank \& Lembaga Keuangan Syariah Lainnya', Depok: Rajawali Pers.

${ }^{18}$ Khotibul Umam, 2015. 'Manajemen Perbankan Syariah', Bandung: CV Pustaka Setia. 
effectiveness of every opinion given by the Sharia Supervisory Board. So that the Sharia Supervisory Board can become a supervisor as well as an advisor to the board of directors in terms of compliance with sharia compliance. ${ }^{19}$ In general, the function and role of the Sharia Supervisory Board are not only limited to the operational activities of Islamic financial institutions, but also has the task of overseeing product development, a channeling of entity funds, and quality of services performed by Islamic financial institutions. The Sharia Supervisory Board as an internal audit of sharia compliance must-have skills and minimum criteria such as understanding in the economy, law, and financial analysis system to monitor any deviations and violations of sharia compliance. The decision of the National Sharia Council of the Indonesian Ulema Council No. 3 of 2000 concerning Guidelines for Implementing Sharia Supervisory Board Members' Determination of Shariah Financial Institutions. Regulates the Sharia Supervisory Board membership requirements. These requirements are to have a moral character, have expertise in the field of muamalah sharia expertise and knowledge in finance, commit to developing sharia finance and have a letter of ratification from the National Sharia Board to become a sharia supervisor.

The difference between conventional capital markets and Islamic capital markets is that there is a Sharia Supervisory Board. The duties and powers of the Sharia Supervisory Board are regulated by the Indonesian Ulema Council and regulated in the law, based on the Decree of the Indonesian Ulema Council Leadership Board regarding the Management Structure of the National Sharia Council in the resolution of the Indonesian Ulema Council Kep-98 / MUI / III / 2001, Sharia Supervisory Board is a body that exists in an Islamic financial institution and is tasked with overseeing the implementation of the National Sharia Council in the Islamic financial institution. The Sharia Supervisory Board is granted and dismissed through a General Meeting of Shareholders after obtaining reserves from the National Sharia Board.

The National Sharia Council is a part of the Indonesian Ulema Council which is tasked with fostering the application of sharia values in economic activities such as banks, insurance, and mutual funds. The National Shariah Board expert also consists of scholars, practitioners, and experts in the economy and sharia muamalah. The National Sharia Council expert was elected and passed by the Indonesian Ulema Council for four years. The National Sharia Council is a body that has the power to issue fatwas on types of activities and products of Islamic finance and to oversee the application of the fatwa referred to by Islamic financial institutions in Indonesia.

\section{The Importance of the Sharia Supervisory Board}

Islam is a complete and universal system of life to compile and provide dynamic and easy directions for all aspects of life, including business and financial affairs. ${ }^{20}$ In Arabic, the word most closely related to the word supervision is the word

\footnotetext{
${ }^{19}$ Khaerul Umam, 2013. 'Manajemen Perbankan Syariah', Bandung: CV Pustaka Setia.

${ }^{20}$ Muhammad Syafii Antonio, 2010. 'Bank Syariah: dari Teori ke Praktik', Jakarta: Gema Insani Press, 2010
} 
"muraaqabah". ${ }^{21}$ The meaning of the word watch in Islamic literature is contained in the word "hisbah" which means ihtisab which is to examine, administer, view, prevent, or detain. Al-Hisbah means to think, think and reason or perform religious duties calling for good and preventing evil acts. ${ }^{22}$ From the understanding of Al-Hisbah, the conclusion that can be drawn is that the implementation of hisbah in the management system can increase efficiency and may indicate the abuse of power. Besides, surveillance can also prevent fraud and all forms of misconduct, excluding Islamic financial institutions. The Quran also discusses the concept of surveillance, which is in QS Ali-Imran [3]: 104 which means: "And let there be [arising] from you a nation inviting to [all that is] good, enjoining what is right and forbidding what is wrong, and those will be successful."

This verse shows that God commands some people who call for good deeds and forbid them from doing evil. Based on this verse, the concept of surveillance can be adapted to many aspects of human life. So is the concept of oversight in Islamic financial institutions. Supervisory institutions in Islamic financial institutions aim to ensure that Islamic financial institutions are always conducting activities following Islamic law principles. Supervision also serves to prevent Islamic financial institutions from engaging in activities that are contrary to Islamic law principles. Besides, God also mentions in the QS Al-Mujadilh [58]: 7 which means:

"Have you not considered that Allah knows what is in the heavens and what is on the earth? There is in no private conversation three but that $\mathrm{He}$ is the fourth of them, nor are there five but that He is the sixth of them - and no less than that and no more except that He is with them [in knowledge] wherever they are. Then He will inform them of what they did, on the Day of Resurrection. Indeed, Allah is, of all things, Knowing."

The Qur'anic verse teaches that God will always oversee human treatment. Every human treatment will be rewarded good and punished for bad deeds on the Day of Judgment. Therefore, the concept of supervision is not something new in Islam. This is also reinforced again in the verses of the QS Qaf [50]: 17-18 which means: "When the two receivers receive, seated on the right and the left. Man does not utter any word except that with him is an observer prepared [to record]." These verses show that the concept of surveillance has long existed in Islam. God warns that every human being will always be guarded by angels. The angels will record every human activity. These surveillance values have been used as guidelines for surveillance in Islamic surveillance institutions.

The establishment of a watchdog institution in Islam is aimed at ensuring that the community adheres to the moral values inherent in Islam. In economic activity, the institution of Shariah financial oversight is essential to ensure faith-based supervision in maintaining an honest economy and to benefit the community as a whole. ${ }^{23}$

To carry out the supervisory role, the government is responsible for appointing a person or group of people to carry it out. The person must have certain qualifications

${ }^{21}$ Munawwir, A.W, 1994. 'Al-Munawwir Kamus Arab-Indonesia', Yogyakarta: Unit Pengadaan Buku Ilmiah Keagamaan Pondop Pesantren Al- Munawwir, 1984, h. 557.

${ }^{22}$ Neneng Nurhasanah, 2013. 'Pengawasan Islam Dalam Operasional Lembaga Keuangan Syariah', MIMBAR, Jurnal Sosial Dan Pembangunan, 29.1 (2013), 11. https://doi.org/10.29313/mimbar.v29i1.362

${ }^{23}$ Neneng Nurhasanah, 2013. 'Pengawasan Islam Dalam Operasional Lembaga Keuangan Syariah', MIMBAR, Jurnal Sosial Dan Pembangunan, 29.1 (2013), 11 https://doi.org/10.29313/mimbar.v29i1.362 
to ensure that he can fulfill his obligations following Islamic law. Imam al-Ghazali explained that the ethics of being a guardian comes from three attributes. Such qualities are good science, wara', and morals. ${ }^{24}$ These qualities are necessary because the purpose of surveillance is to protect members of society from fraud and to maintain the wellbeing of the people following God's provisions. In other words, surveillance in Islam is a control mechanism established by Islam to maintain the social order of life. So that everyone is guaranteed safety and meets their basic needs.

The oversight of Islamic financial institutions is to ensure that the institution adheres to Shariah principles. Supervision is an important part of maintaining people's trust. Institutions that exercise oversight will give credit to Islamic financial institutions for conducting activities that are prohibited by shariah principles..$^{25}$ Therefore, the public will believe that the Islamic financial institution will not engage in activities that are contrary to Islamic law principles.

Supervision is necessary to avoid any deviation from the rules. Supervisory activity is also a form of regulation that does not conform to its original purpose. Fortunately, a weak surveillance system will encourage fraud and misconduct that could endanger the relevant party or the public.

Proper regulation and standards are essential to ensure the development of the takaful industry, supervision, and monitoring of takaful operators through effective supervision by the authorities. It aims to ensure that players operate in a manner consistent with sharia principles. Lack of oversight, checks, and balances, and excessive exposure to risk are among the factors that can lead to disadvantages not only to the takaful industry but to the financial system as a whole. Therefore, supervisory institutions must be tasked to regulate the activities of the Shariah-compliant capital market business following shariah principles.

\section{Regulation of Sharia Supervisory Board in The Sharia Capital Market}

Indonesia does not yet have a law specifically addressing the Islamic capital market. The development of the Islamic capital market is so rapid in Indonesia. The Islamic capital market still uses Law No. 8 of 1995 concerning the Capital Market. The problem is that the Act is based on conventional capital market activities. So some sharia principles have not been accommodated by these laws.

To overcome these problems, the Indonesian Financial Services Authority issued several regulations regarding the Islamic capital market. This is intended so that the activities of the Islamic capital market are always protected by a clear legal basis. Given the public interest in the Islamic capital market is quite high.

Section 7 and 8 of the Regulation of the Indonesian Financial Services Authority Number 15/Pojk.04/2015 states that every party conducting sharia activities in the capital market must have a Sharia Supervisory Board. More specifically, Section 3 of the

\footnotetext{
${ }^{24}$ Aliyah, 2004. Sistem Pemerintahan Peradilan dan adat Dalam Islam, Jakarta: Khalifa, h.71.

${ }^{25}$ Neneng Nurhasanah, 2013. 'Pengawasan Islam Dalam Operasional Lembaga Keuangan Syariah', MIMBAR, Jurnal Sosial Dan Pembangunan, 29.1 (2013), 11. https://doi.org/10.29313/mimbar.v29i1.362
} 
Indonesian Financial Services Authority Regulation Number 17/POJK.04/2015 states that Sharia Issuers or Sharia Public Companies must have a Sharia Supervisory Board. Through these regulations, it is known that the Sharia Supervisory Board is a party that must exist in an institution that will conduct activities in the Capital Market. Explained in more detail, the parties that are required to have a Sharia Supervisory Board are Sharia Issuers. The definition of an issuer based on the Capital Market Law is a party conducting a Public Offering. Whereas the definition of sharia issuers based on Financial Services Authority Regulation Number 17/Pojk.04/2015 is an Issuer whose sections of association declare business activities and types and ways of managing their business based on Sharia Principles in the Capital Market.

The Sharia Supervisory Board's task in the Capital Market under Section 10 of the Financial Services Authority Regulation Number 15/Pojk.04/2015 is to make a report on compliance with sharia principles. This task is also strengthened by section 6 of the Financial Services Authority Regulation Number 17/Pojk.04/2015 which states that Sharia Supervisory Board Sharia Issuers or Sharia Public Companies are required to prepare annual surveillance reports to shareholders for compliance with Sharia Principles in the Capital Market by Sharia Issuer or Sharia Public Company being supervised. In the Elucidation section of this Act, it is stated that the Sharia Supervisory Board has two duties. First, provide advice and advice to the Directors and Board of Commissioners of companies that carry out activities in the Capital Market on matters relating to sharia aspects. Second, conduct periodic reviews of the application of Sharia Principles in the Capital Market to the company's business activities.

In more detail, section 16 of the Indonesian Financial Services Authority Regulation Number 16 Pojk.04/2015 contains 8 Sharia Supervisory Board tasks in the Capital Market. First, provide advice and advice to the Directors and Board of Commissioners of the company regarding matters relating to Sharia Principles in the Capital Market. Second, oversee the fulfillment of the application of Sharia Principles in the Capital Market in the company's business activities. Third, conduct periodic reviews of the application of Sharia Principles in the Capital Market to the company's business activities. Fourth, give a written warning to the Directors of the company no later than 2 (two) working days after the discovery of irregularities and ask the Board of Directors to immediately make remedies no later than 10 (ten) working days after the receipt of the written warning, with a copy to the Financial Services Authority and the Board of Commissioners. Fifth, safeguarding the confidentiality of company documents, data, and information that is monitored and given advice. Sixth, request data and information from the company in the context of supervising the implementation of Sharia Principles in the Capital Market. Seventh, accompanying companies or representing companies in discussions with the National Sharia Council - Indonesian Ulema Council. Finally, provide a statement of sharia compliance with Sharia Principles in the Capital Market for sharia products or services in the Capital Market.

Based on Section 9 of the Financial Services Authority Regulation Number 15/Pojk.04/2015 and Section 3 of the Financial Services Authority Regulation Number 17/Pojk.04/2015, the Sharia Supervisory Board in the sharia capital market is selected and authorized by the General Meeting of Shareholders or appointed by directors. This 
shows that the government was not involved in the selection of the Sharia Supervisory Board. The authority to choose the Sharia Supervisory Board is left to each company. So that the potential to cause conflicts of interest. This is because the company can terminate the Sharia Supervisory Board. The task of the Sharia Supervisory Board is to oversee if something goes wrong in compliance with sharia principles.

A Sharia Supervisory Board can oversee up to four companies that conduct Sharia Activities in the Capital Market. This provision is based on Section 25 of the Financial Services Authority Regulation Number 16/ Pojk.04/2015. This also raises two potential problems. First, it is about keeping company secrets. Second, it is about the quality of performance. This has the potential to cause problems in terms of quality of supervision. There are several Sharia Supervisory Board tasks in conducting the oversight process. Therefore, special attention is needed in supervising a company so that its activities are following Islamic principles. ${ }^{26}$

\section{CONCLUSION}

The development of Islamic capital markets, both in Indonesia and in the world, is experiencing rapid growth. The Islamic capital market is part of Islamic financial institutions. So that it has a significant role as an institution to develop the economy of society through ways following sharia principles. Therefore, the government also supports the development of the Islamic capital market by providing laws governing the Islamic capital market.

One important element of an Islamic financial institution, including the Islamic capital market, is the presence of the Sharia Supervisory Board. The Sharia Supervisory Board is tasked with overseeing the compliance of sharia in sharia capital market activities. This is very important because the compliance of sharia is the differentiator between the Islamic and conventional capital markets. If Shariah compliance is not carried out then it is the same as conventional capital markets. Therefore, the Indonesian Financial Services Authority has regulated the Sharia Supervisory Board by issuing Financial Services Regulations relating to Islamic Capital Markets.

The existence of the Sharia Supervisory Board in the Islamic capital market has been required through section 7 and section 8 of the Financial Services Authority Regulation Number 15/Pojk.04/2015 and section 3 of the Financial Services Authority Regulation Number 17/ Pojk.04//2015. While the Sharia Supervisory Board's duties are explained in Section 10 of the Financial Services Authority Regulation Number 15/Pojk.04/2015, section 16 and section Financial Services Authority Regulation Number 16/Pojk.04/2015, and Section 6 of the Financial Services Authority Regulation Number 17/Pojk .04/2015. In this way, it is expected that sharia compliance in the Islamic capital market can continue to be monitored by the Sharia Supervisory Board. So that activities in the Islamic capital market are following Islamic principles.

\footnotetext{
26 Bagas Heradhyaksa and Ruzian Markom, 2018. 'Jurisdiction of Sharia Supervisory Board in Indonesian Takaful Industry' IOP Conf. Ser.: Earth Environ. Sci, (2018) <doi:10.1088/17551315/175/1/012177>.
} 


\section{REFERENCES:}

Abduh, Muhammad, 'Penerapan Prinsip Ekonomi Islam Dalam Pasar Modal Syariah', Jurnal 'Adliya, 9.1 (2015) 99-114.

Aji, A.M.; Yunus, N.R. Basic Theory of Law and Justice, Jakarta: Jurisprudence Institute, 2018.

Aliyah. Sistem Pemerintahan Peradilan dan adat Dalam Islam, Jakarta: Khalifa, 2004.

Antonio, Muhammad Syafii. 'Bank Syariah: dari Teori ke Praktik', Jakarta: Gema Insani Press, 2010.

Faozan, Akhmad, 'Optimalisai Peran Dewan Pengawas Syariah Pada Lembaga Keuangan Syariah', Jurnal El-Jizya, II.1, (2014) 23-40.

Fauzan, M, and Dedi Suhendro, 'Peran Pasar Modal Syariah Dalam Mendorong Laju Pertumbuhan Ekonomi Di Indonesia', Prociding SENDI, 2019, 978-79

Gusniarti, 'Perdagangan Saham di Pasar Modal Syariah Perspektif Ekonomi Syariah (Studi Kasus Bursa Efek Indonesia)' . Al-Intaj, 1(1), (2015) 1-18.

Heradhyaksa, Bagas; and Markom, Ruzian 'Jurisdiction of Sharia Supervisory Board in Indonesian Takaful Industry' IOP Conf. Ser.: Earth Environ. Sci, (2018) $<$ doi:10.1088/1755-1315/175/1/012177>.

Maggalatung, A.S.; Aji, A.M.; Yunus, N.R. How The Law Works, Jakarta: Jurisprudence Institute, 2014.

Muhammad, 'Bank \& Lembaga Keuangan Syariah Lainnya', Depok: Rajawali Pers, 2020.

Muklis, Faiza, ‘Perkembangan Dan Tantangan Pasar Modal Indonesia', Al Masraf (Jurnal Lembaga Keuangan Dan Perbankan), 1.1 (2016), 1-12

Munawwir, A.W, 'Al-Munawwir Kamus Arab-Indonesia', Yogyakarta: Unit Pengadaan Buku Ilmiah Keagamaan Pondop Pesantren Al- Munawwir, 1984.

Nurhasanah, Neneng, 'Pengawasan Islam Dalam Operasional Lembaga Keuangan Syariah', MIMBAR, Jurnal Sosial Dan Pembangunan, 29.1 (2013), 11 https://doi.org/10.29313/mimbar.v29i1.362

Nurlita, Anna, 'Investasi Di Pasar Modal Syariah Dalam Kajian Islam', Kutubkhanah: Jurnal Penelitian Sosial Keagamaan, 17.1 (2015), 1-20<http://ejournal.uinsuska.ac.id/index.php/Kutubkhanah/article/download/806/766>

Ramadhan, Sri, 'Pasar Uang Dan Pasar Modal Dalam Perspektif Ekonomi Islam', AlMasraf : Jurnal Lembaga Keuangan Dan Perbankan, 1.2 (2016), 197-210 http://journal.febi.uinib.ac.id/index.php/almasraf/article/view/56

Setiawan, Budi, ‘Perbandingan Kinerja Pasar Modal Syariah Dan Konvensional : Suatu Kajian Empiris Pada Pasar Modal Indonesia', Jurnal Ilmiah Ekonomi Global Masa Kini, 8.1 (2017), 35-40

Subaidi, 'Rekonstruksi Hukum Pasar Modal Syariah Dalam Memberi Jaminan Kepastian Hukum', Istidlal: Jurnal Ekonomi Dan Hukum Islam, 1.2 (2017), 15566 https://doi.org/10.35316/istidlal.v1i2.105

Umam, Kaherul, 'Manajemen Perbankan Syariah', Bandung: CV Pustaka Setia, 2013. Ai Nur Bayinah, Sepky Mardian, Sri Mulyati, Erina Maulidha, 2018. Akutansi Asuransi Syariah, Jakarta: Salemba empat. 